\begin{abstract}
CONOR O'BRIEN, 'Attitudes to St Cuthbert's Body during the Nineteenth Century'. St Cuthbert's tomb in Durham Cathedral was opened in 1827, occasioning the start of a cycle of polemic and counter-polemic between Protestant and Roman Catholic writers throughout the rest of the century. The excavation of 1827 aimed to disprove the medieval legends about the incorruption of Cuthbert's body but it (and the many texts which debated its findings throughout the course of the nineteenth century) must be understood in the light of local religious controversy as much as of Victorian antiquarianism. The texts which addressed the issue of Cuthbert's body in the years which followed were concerned with religious, as well as historical, truth and reveal shifting attitudes in both the Anglican and Catholic communities to the role of saints, miracles and relics within their own forms of Christianity. While this paper mainly concerns a comparatively small element of Victorian religious debate, one focused upon issues of local interest and identity, it problematizes some of the traditional paradigms used to understand nineteenth-century scholarship. Not the increasing secularisation of historical practice and antiquarianism, but the continuing, albeit changing, importance of Durham's patron saint, is the most striking feature of the dispute.
\end{abstract}

Keywords: Durham; St Cuthbert; antiquarianism; sectarianism; miracles; sanctity 


\title{
ATTITUDES TO ST CUTHBERT'S BODY DURING THE NINETEENTH CENTURY*
}

\section{CONOR O'BRIEN}

\author{
Churchill College, Cambridge
}

If St Cuthbert thought that he would find in death the peace and withdrawal from the affairs of men which he had sought in life, he was proved sorely wrong. The monks of Lindisfarne convinced Cuthbert, who had initially desired to be buried upon Farne Island, where his hermitage had long been, to allow them inter him on Lindisfarne. ${ }^{1}$ Only eleven years after his death, in 698, they decided to translate Cuthbert's relics to a new shrine beside the high altar, in the process discovering his body to be as fresh and intact as if he were still alive. ${ }^{2}$ Following Viking raids, the community fled Lindisfarne in 875 taking Cuthbert's preserved body and their other precious relics with them. After much wandering, Cuthbert lay at Chester-Le-Street from 882 until 995, when again the community moved on - this time to their final home at Durham. ${ }^{3}$

But even in that city Cuthbert's corpse could not rest in peace. On the occasion of its translation into the magnificent new cathedral of William of St Calais the body was examined again in 1104, subjected to a quite vigorous man-handling and found again to be incorrupt, with the limbs still flexible. ${ }^{4}$ Cuthbert's shrine at Durham was to become one of the major sites of pilgrimage in England, indeed one of the richest such shrines in all of Europe. As earthly governors of St Cuthbert's patrimony, the Prince-Bishops of Durham extended their authority, and under the banner of St Cuthbert the people of the North-East of England on more than one occasion marched to victory against the Scots. ${ }^{5}$ 
But all good things come to an end and not even one of England's most popular saints could withstand the Henrician reformation. In 1537 Cuthbert's shrine was smashed open by the king's commissioners, and for the next five years the body lay, disentombed, in the cathedral vestry before a royal order was made to rebury Cuthbert under the site of his now demolished shrine. The story arose that the commissioners, expecting only to find a heap of bones, had been shocked to discover the saint's body still incorrupt - the only imperfection being on the left leg, broken by one of their workmen's hammerblows. ${ }^{6}$ But from 1542 Cuthbert lay, apparently peacefully, in the cathedral, undisturbed as the world changed all about him.

That is until the nineteenth century, when the saint was to be dug up again - not just once, but twice. Antiquarian and scholarly interests played a part in the excavations at Cuthbert's tomb, but they were overlaid with important confessional interests. This surprising flurry of activity around the tomb of Cuthbert and the resultant writings discussing his relics reveal the extent to which long after the Middle Ages and the Reformation, Cuthbert's relics remained a focus for religious devotion, and thus a cause for religious strife. The cult of the saints may seem far removed from Victorian Durham, and some certainly felt it ought to be, but Cuthbert's body retained a power over men, even over those who went out of their way to belittle it. The excavations of Cuthbert's tomb and the writings they inspired during the nineteenth century were driven as much by the search for religious, as for academic, truth. Much of the interest in Cuthbert arose from the particular circumstances of Victorian Durham and the North-East of England, reflecting the saint's ongoing importance for local identities, but the issues revealed by this local debate shed light on the wider English context. 
The initial event which led to much of the heated debate surrounding Cuthbert's body took place on 17 May 1827. On that day the tomb of Cuthbert was opened in the presence of three canons of the cathedral, the Reverends William Nicholas Darnell, William Stephen Gilly and James Raine, the Librarian of Durham Cathedral and apparent leader of the enterprise. Raine, already making a name for himself in scholarly circles, had apparently been working on a book on St Cuthbert for two years already. ${ }^{7} \mathrm{He}$ published his magnificently illustrated and impressively erudite volume the following year, giving a detailed description of the items he had found in Cuthbert's tomb. ${ }^{8}$ These included a host of objects of great archaeological interest: fragments of the Anglo-Saxon carved coffin in which Cuthbert had been placed in 698; a gold pectoral cross; a portable altar of oak and silver; scraps of elaborately decorated silk; and a skeleton which Raine declared to be that of Cuthbert.

The excavation of the grave was an act of great scholarly importance and the materials Raine and his colleagues discovered remain of significance today. ${ }^{9}$ But Raine's book was not a dry and academic tome; rather it was a vigorous polemic, claiming (in the very last words of the text) that the investigation of 1827 'completely disproves that tale of centuries, invented for interested purposes in a superstitious age - the incorruptibility of St. [sic] Cuthbert. ${ }^{10}$ Raine wanted to lay bare a tale of monkish imposture: of how the possessors of Cuthbert's relics had consistently and deliberately from 698 onwards concealed the fact of the saint's decomposition in order to promote the material interests of their own church. Driven by greed, they had promoted the gross impiety and blasphemy of the cult of the saints during that period when England had lain under the superstitious pall cast upon it by the authority of Rome. The villainies of the monks of Durham knew no bounds - not even stopping at the poisoning of William the 
Conqueror. ${ }^{11}$ For Raine, everything else seems to have been secondary in his account to proving the cult of Cuthbert to be one monstrous sham. ${ }^{12}$

The ferocious and sometimes wild polemic of Raine's text seems to reflect something of the fevered haste in which the actual investigation of the tomb had taken place. While Raine's account gives the impression of an officially-authorised archaeological investigation by members of the Cathedral Chapter, Gilly was later to give a very different account. Gilly claimed to have arrived on the scene after the tomb had been opened, having been alerted by the noise, to discover Raine actually standing in the tomb treading upon the bones beneath his feet. ${ }^{13}$ Even the official account acknowledges that the entire investigation took place in a great rush; the tomb was opened and the body re-interred in a new coffin in a single evening. ${ }^{14}$ The overall impression is not of a triumph of cautious and disinterested scholarship, but of a much more ad hoc and disorganised investigation. Indeed there is good reason to suppose that the excavation was not in the slightest disinterested.

The tomb was opened on 17 May; the dedication of the new Roman Catholic church (the first in Durham since the Reformation) in honour of St Cuthbert at Old Elvet took place barely a fortnight later on 31 May. ${ }^{15}$ Even the clergy of Durham Cathedral itself later acknowledged that the timing had not been accidental. ${ }^{16}$ By opening the tomb, the Anglican cathedral chapter could reassert its possession of Durham's patron saint, while simultaneously undermining the Catholic belief in the incorruption of Cuthbert's relics. This Durham drama played out against the backdrop of the approaching climax of the national campaign for Catholic Emancipation which had met fierce resistance from successive bishops of Durham. The new bishop, the scholarly William Van Mildert, was 
one of the firmest of those to resist Emancipation publically, and his long-reigning predecessor, the aristocratic Shute Barrington, had been equally opposed. ${ }^{17}$

Barrington's propensity to take public swipes at the Roman Catholic faith and his episcopal charge of 1806 had led to a seemingly never-ending round of polemical pamphlets, wherein a host of Durham clergy had done battle with the Roman Catholic priest and historian, John Lingard. ${ }^{18}$ The diocese was thus no stranger to religious controversy, and Lingard, by now fully embarked on his career as an historian of importance, was a tried and tested pamphleteer by the time of the excavation of Cuthbert's tomb. It was his reputation as a polemicist, as much as that as a scholar, which encouraged the president of Ushaw College, Durham's local Roman Catholic seminary where Lingard had once been a member of the faculty, to bring his attention to Raine's work on St Cuthbert. Ushaw College had a clear communal interest in defending the honoured reputation of its great saint and in exculpating Catholic devotion to Cuthbert from accusations of dishonesty. ${ }^{19}$ The seminary's president, Dr Thomas Youens, therefore sent Lingard a copy of Raine's book, along with a request to respond.

Lingard's reply by way of pamphlet provided a brief, but in places powerful, response to Raine. The most obvious flaw with the latter's Saint Cuthbert was that it was evidently not a work of disinterested history, and Raine's clear zeal to damn the medieval monks at every possible opportunity undermined any claims to scholarly impartiality. Lingard repeatedly pointed out the fervour and the bias which underpinned the proceedings of May 1827 and which he saw as opposed to everything for which an historian and scholar should stand. ${ }^{20}$ Dr Raine, he declared, 'writes evidently under the full influence of religious prejudice ... and betraying in almost every page the most feverish anxiety to discover, or excogitate, proofs of fraud against the ancient clergy of 
Durham'. ${ }^{21}$ He went on to sum up: 'Throughout the inquiry [Raine, Darnell and Gilly] have shewn but little of that calm dispassionate judgment, which alone can entitle them to the confidence of their readers. ${ }^{22}$ Such criticisms of course depended on the implicit claim that Lingard himself was under no such confessional influence, but entirely dispassionate. When compared to both Raine and some of his own co-religionists, so indeed he appears to have been. For Lingard's attempt to use his own calm, dispassionate judgement proved to be not entirely welcomed by his patrons at Ushaw.

Raine's book had not simply aimed to scotch belief in the medieval tradition of Cuthbert's incorrupt body; it had also sought to dismiss a more recent tradition about the location of Cuthbert's body, incorrupt or not. Sometime in the centuries since the Reformation the rumour had begun to circulate that Cuthbert was not buried in the former location of his shrine at all; rather, that he was in a secret location in the cathedral, known only to some of the (Roman Catholic) faithful. Three members of the English Benedictines kept the secret according to one version of the story, passing it down from generation to generation. Different variants of the legend circulated: some said that the Catholics had dug up Cuthbert during the reign of Mary to protect him from future degradations; others that Cuthbert had never been placed in the tomb at all in 1542 . In the first decades of the nineteenth century this tradition came to the attention of the British reading public more than once. Scott mentioned it in Marmion in $1808 .{ }^{23}$ In 1812 Bishop Milner (the Roman Catholic Vicar Apostolic of the Midland District) discussed it briefly in a scholarly paper on St Cuthbert's gospel-book. ${ }^{24}$

Raine had given the legend short shrift, ascribing it to a mistake of the late seventeenth-century hagiographer Alban Butler. ${ }^{25}$ Raine did not have access to Roman Catholic, and especially Benedictine, records which clearly showed that the secret had 
been circulating in the early seventeenth century before Butler. ${ }^{26}$ Lingard was doubtful of Raine's attempt to blame Butler for the legend, but in the body of his text he followed a cautious route, neither acknowledging nor denying that the skeleton found in 1827 had been that of Cuthbert. ${ }^{27}$ Only in a note on the final page of errata published with Lingard's pamphlet is a firm judgement on the corpse's identity made: 'I have supposed that the body remained undisturbed in the grave from 1541 to 1827 , because we have no proof of the contrary; but I am strongly inclined to give credit to that part of the tradition of the monks which states, that the body was taken out of the grave during the reign of queen Mary. ${ }^{28}$

But this comment did not come from John Lingard at all. The community at Ushaw College had expected their one-time member to defend the Roman Catholic traditions concerning Cuthbert to the full: not only had Cuthbert been genuinely incorrupt in the past, but he was almost certainly incorrupt now, safe in his secret location from the prying eyes of impious Protestant clerics. Unfortunately, Lingard genuinely believed that Raine had found the real skeleton of St Cuthbert; fortunately, he had sent the manuscript of his pamphlet to the Ushaw community with permission to do with it as they would. ${ }^{29}$ And so a statement was inserted to make the distinguished polemicist seem to defend the legend of Cuthbert's secret burial. Lingard allowed such mendacity in an anonymously published pamphlet, but he would later freely announce his belief that the body constituted the genuine remains of Cuthbert in the historical works published under his own name. ${ }^{30}$

Some other Catholic writers shared Lingard's scholarly ideals and were willing to accept that the tale of Cuthbert's secret burial was probably no more than a myth. Dom Athanasius Allanson, the historian of the English Benedictines, speculated that the 
discovery of a body proved the legend to be untrue. Since there was no talk of any substitution of a fake Cuthbert in the story as Allanson had heard it, by rights there should have been no body in the tomb at all. The fact that a skeleton had been found under Cuthbert's gravestone would suggest, therefore, that the saint's relics had never been moved. ${ }^{31}$ Allanson was a scholar writing within the confines of the English Benedictine community, his history only circulating in manuscript form. When others took up their pens in the public arena, however, polemic was the order of the day and the Durham Cathedral Chapter's 'resurrection-men' were roundly condemned as being misguided, blinded by bigotry, from start to finish. ${ }^{32}$ This was especially the case if the writers counted St Cuthbert's College, Ushaw as their alma mater - as a large number of the Catholic clergy in Victoria England did.

Charles Eyre, scion of a distinguished northern Catholic family, brought out a volume almost as grand and weighty as Raine's Saint Cuthbert in 1849. Dedicated to the members of Ushaw College, where Eyre had trained for the priesthood, The History of St. Cuthbert declared that it would allow the reader to decide the truth of the matter and then set about carefully directing what that decision ought to be: 'The reader ... from the careful exclusion of Catholics in 1827 , will know what value to attach to evidence collected during a search made in any spirit rather than that of a candid and honest examination. ${ }^{33}$ The very fact that Raine had not discovered an incorrupt body was deemed to prove that he could not have discovered Cuthbert's body, which necessarily had to be incorrupt. ${ }^{34}$ Eyre, sublimely resistant to alternatives, took the saint's traditional incorruptibility as a matter of faith. He accepted that Dr Lingard felt differently, but Eyre declared himself convinced that the real body was carefully hidden elsewhere in the cathedral, a decoy having been substituted sometime during Mary's reign. The great 
English saint was hidden from view while his nation was in schism; Eyre hoped that the return of England to the Roman fold would herald the return of Cuthbert's relics. ${ }^{35}$

Raine's Saint Cuthbert had been more than just a blast in a local sectarian squabble; while intended for conflict with the absurdities of medieval Catholicism, it also by its very grandeur and erudition was meant to be a monument to the learning to which an Anglican cathedral could be home. Lingard's Remarks belonged to the established tradition of pamphleteering, where publically trashing one's opponent's arguments was key; Eyre's book, however, had a more constructive purpose - it was an attempt to produce as magisterial a volume as the original Saint Cuthbert. Lingard seemed to write for a scholarly audience who existed beyond confessional differences; Eyre's volume was based on a very clear sense of group identity, unlikely to convince anyone not already devout but sure to inspire a sense of pride in its readers at Ushaw and similar communities: ${ }^{36}$ which is not to say that the Dean and Chapter of Durham were unaware that their Librarian's efforts had not put paid to the old Roman Catholic legends, but in fact given them a new lease of life.

Consequently when in September 1867 a Mr Swinburne, the Anglican son of a Roman Catholic family, brought forward a document recording the directions to the true location of Cuthbert's body (at least according to one version of the hydra-like legend), the Cathedral authorities treated it with the utmost seriousness. The slipshod affair forty years previously was to be put behind them: the chapter took a formal decision to investigate and Dean Waddington invited local Roman Catholic clergy to watch the proceedings. The text which had come into the Chapter's possession seemed to indicate the staircase to the clock tower as the spot to look. ${ }^{37}$ The excavations proved negative despite two days of digging at two different staircases to see if anything could be found. ${ }^{38}$ 
Durham Cathedral had faced the doubts about Cuthbert's body squarely and, apparently, triumphed.

In fact, the investigations of 1867 appear to have settled very little. A Protestant hagiographer could write, seemingly without hint of controversy, that 'the dry bones of the saint were discovered' in $1827,{ }^{39}$ a Roman Catholic suspected that the true location of the body was still known only to the Benedictines. ${ }^{40}$ When 1887 , and the twelvehundredth anniversary of Cuthbert's death, came around Charles Eyre (by now the Roman Catholic archbishop of Glasgow) produced another edition of his book on Cuthbert, with hardly a change in his views on the body. All he did was add a set of appendices consisting of newspaper accounts of the 1867 investigations which cast sufficient doubt on whether the investigations had even been looking in the right place to begin with so as to imply the question remained entirely unsettled. ${ }^{41}$ Not everyone proved so dogged in their conviction: the events of 1867 have convinced Edward Consitt rather more thoroughly. Fr. Consitt had attended the excavations as a Catholic representative and in his anniversary volume on St Cuthbert he readily admitted that it appeared that Raine had indeed found the true relics. ${ }^{42}$

Of course he did not let the issue lie there. The incorruptibility of Cuthbert up until 1542 was taken as a given by Consitt. Hence, concerning the decay into a dry skeleton since then: 'What difficulty is there in believing that when His servant ceased to be treated with honour and veneration, and his miraculous state no longer inspired the devotion of the people, God should have permitted his Body to fall into decay! ${ }^{43}$ Consitt transformed the material state of Cuthbert's body into a metaphor for the faith of the people of England. The decay of the latter had led clearly to the decay of the former. The body of St Cuthbert provided in fact a mirror for the religious state of the nation. Consitt 
ended his book with a vivid contrast between Durham on the feast of St Cuthbert in 1448 and in 1887. The one was full of devotion, colour and passion; the other cold, dull and uncaring. ${ }^{44}[\mathrm{~T}]$ he sacred Body of our great patron still reposes within the walls of his cathedral at Durham', but, without the true sacraments of the faith ('no longer an altar, nor priest, nor sacrifice'), the beauty of the cathedral had been rendered meaningless. ${ }^{45}$

Raine had condemned the cult of the saints as being in essence impious, contrary to true Christian religion. Consequently, almost no evil was beyond belief where the supporters of so blasphemous a practice were concerned. Eyre and Consitt instead embraced the cult of St Cuthbert and declared that in fact devotion to the saints was a means of measuring true devotion to God. And as the century passed Church of England clergy began to wonder if that might not be true - and as they did that, they seem to have become more willing to believe that perhaps Cuthbert had been incorrupt after all; perhaps there was some truth in tales of monkish secret burials. Thus Roman Catholics were not the only ones to mark Cuthbert's anniversary in 1887. In January of that year the Revd J. T. Fowler preached in York Minster on St Cuthbert and appealed for donations to fund the cathedral's planned installation of the Cuthbert Window. His sermon revealed a sympathetic attitude to the medieval cult of Cuthbert's relics: 'They felt that in honouring what had been the earthly tabernacle, they were honouring him who was living before the throne, and that in honouring the departed saint they were honouring his God. ${ }^{46}$

Few things show the shift in Anglican attitudes to the cult of the saints more than the Tractarian Sabine Baring-Gould's massive Lives of the Saints. ${ }^{47}$ Baring-Gould, having expressed the hope that both Roman and Anglo-Catholics would welcome his work, was perfectly willing to extract his account of Cuthbert from that of the Count de 
Montalembert in his Monks of the West. ${ }^{48}$ Perhaps more surprisingly he was willing to go beyond Montalembert in order to cast doubts on whether Raine had discovered the real body of Cuthbert at all. Baring-Gould recounted the details of both the 1827 and 1867 excavations and still let his life of Cuthbert end with the declaration that 'it is difficult not to conclude that the garments and shrine were those of Cuthbert, but that the body [found by Raine] was not his, but was one which had been substituted for it. ${ }^{49}$ Thus a Church of England country vicar, self-consciously Catholic though not always taken with the more Roman saints, happily gave credence to what had once been exclusively Roman Catholic beliefs. ${ }^{50}$

Ushaw College continued to be a bastion defending the traditional legends. The old Roman Catholic attitudes to Cuthbert's body found no greater champion than Revd William Brown, who, as both faculty member at St Cuthbert's College and incumbent at St Cuthbert's Church, Old Elvet, seems to have felt doubly under the saint's patronage. He started from the same assumption as Eyre: Cuthbert's body was incorrupt, hence Cuthbert's body had not been found until an incorrupt body had been found.$^{51}$ Brown was schizophrenic in his attitude to Raine's theories. On the one hand he followed the path established long before by Lingard: the 1827 investigation had arisen from bigoted impulses, which rendered it untrustworthy from start to finish, and anyway had been hastily and shoddily undertaken. ${ }^{52}$ On the other hand, Brown was perfectly willing to believe Raine's description of a skeleton cunningly dressed up to give the impression of an undecayed body. This, Brown agreed, was certainly a Catholic ploy: not one to fool the medieval masses however, but rather to dupe the Protestant iconoclasts when the real St Cuthbert was spirited out of the vestry sometime between 1537 and $1542 .^{53}$ 
Did this forceful, and at times fanciful, rejection of Durham Cathedral's claim to have Cuthbert's body under the flagstone inscribed with the saint's name have anything to do with the chapter's decision to re-open the tomb in 1899 ? Certainly the possibility of settling the question of the skeleton's identity seems to have been raised in the discussions preliminary to the new excavation. ${ }^{54}$ Once again the driving force behind the project came from the scholarly activities of the cathedral librarian. But William Greenwell went about things very differently from James Raine. All the contemporary accounts agree that it was Dr Greenwell's desire to see if more of the original oaken coffin could be found in the tomb which led to the decision to open it. It was eventually decided not to touch the body. ${ }^{55}$ Providence, however, had decided otherwise. As the hastily-made coffin of 1827 was gingerly lifted from the tomb it collapsed, spilling out bones in a heap. ${ }^{56}$

It was a rather unfortunate start to an enterprise which the cathedral chapter had carefully planned in order to avoid all the mistakes of the past. Representatives from Ushaw had been invited to the opening of the tomb on 1 March, and so arch-doubter Fr Brown attended alongside Dr Kitchin (the Dean) and many of the cathedral's canons (the learned Greenwell and Fowler in the lead). Faced with the prospect of putting Cuthbert back together again, the canons decided to avoid the rush of 1827 and so the tomb remained open for almost two weeks. The reverence of the proceedings was conspicuously mentioned again and again in the official accounts of the investigations (and attested to by Fr Brown) and when the body finally returned to the tomb the Dean, clad in surplice, performed a short service. ${ }^{57}$ It is clear that active steps had been taken to avoid giving offence or cause for trouble of the type Raine's investigation had led to 
earlier in the century; indeed the 1827 opening of the tomb received frequent negative comment throughout the reports of the Anglican investigators from 1899. ${ }^{58}$

Nonetheless the canons for the most part seem to have been satisfied that the result of the investigations strengthened their claims to possess Cuthbert's body, though they never asserted this dogmatically. The Revd Mr Taylor's paper to the Society of Antiquaries of Newcastle-upon-Tyne on the excavation seems to have assumed that the skeleton was that of Cuthbert, but Greenwell (chairing the meeting) was almost suspiciously unwilling to commit himself either way. ${ }^{59}$ Fowler believed that the evidence was now clearly on the side of the relics being genuine but does not appear to have been overly concerned to convince the sceptical William Brown of this. ${ }^{60}$ Dr Selby Plummer declared that his medical investigation made no attempt 'to settle any question of identity', before going on to conclude that the medical evidence 'is corroborative of the genuineness of the relics and condemnatory of any substitution. ${ }^{91}$

The Anglican community's increasing unwillingness to push their claims to the point of outright disagreement seems clear in Dr Kitchin's words seeking to sum up the debate over Cuthbert's body when, in the Victoria County History published at the dawn of the twentieth century, he declared: 'Whether or no Durham Cathedral is still in charge of the genuine remains of St. Cuthbert is a question that has often been discussed with some unnecessary warmth.' ${ }^{62}$ James Raine was chided for infusing 'far too much local feeling and prejudice' into his writings on the subject. ${ }^{63}$ It was acknowledged that the 1899 investigation had not provided unimpeachable proof on the matter. Nonetheless the remains in the tomb were likely to be genuine. ${ }^{64}$ An irenic, imperturbable quiet had settled on Durham Cathedral's attitudes to Cuthbert. The chapter could rest content knowing that they probably had Cuthbert's relics, and that they were treating them with 
the respect the bones of such a holy man deserved. The days of canons leaping into pits full of bones were long gone.

Thus when William Brown once more went on the offensive in response to Kitchin's article, the clergy of Durham Cathedral could not summon up enough fire to respond. It was the medical doctor, Selby Plummer, who engaged in debate with Brown in the letters page of the Durham County Advertiser ${ }^{65}$ In that exchange Brown, for all that he presented sensible objections to the results of the 1899 investigation, comes across as something of a crank, who continues to write letters long after anyone the replies have ceased. But perhaps it was the drive of the underdog, the nagging feeling that one has been hard done by and that possession of a treasure has been too long denied. ${ }^{66}$ For some commentators at least, Cuthbert's rest seems to have been as uneasy at the end of the Victorian era as it had been throughout the previous century.

Attitudes and responses to the issue of Cuthbert's body clearly changed a lot on both sides of the religious divide during the century. Raine had been convinced that the medieval cult of the saints was blasphemous and idolatrous since it undermined the uniqueness of the true mediator between God and men (I Timothy 2. 5) ${ }^{67}$ It is perhaps dangerous to read too much into actions so ambiguous and ill-recorded, but leaping into the tomb savours as much of wishing to grind the once-revered bones under foot, as it does of antiquarian zeal. Whether the slap-dash nature of the coffin built in 1827 was by accident or design, the investigators of 1899 were all shocked at the apparent irreverent shoddiness of it. '[T]his frail and shabby packing-case', 'made of such rubbishly [sic] deals', suggests a studied, and theologically-driven, insult to its contents. ${ }^{68}$ Undoubtedly the chapter of 1899 decided to make Raine out to be a villain in order to defuse any potential offence their own dealings with the saint's body might have occasioned. ${ }^{69}$ 
Nonetheless, there is a real sense from the Anglican commentators of 1899 that a dignified and reverent resting-place for Cuthbert was something piety demanded. It was not a feeling Raine would necessarily have shared.

If the aggression of the Durham Cathedral clergy to the body of their own patron saint in 1827 had distinctly mellowed by 1899 , the language of the Roman Catholic response became all the more aggressive. Lingard pointed out that 'the truth or falsehood' of Roman Catholicism did not have 'any connexion with the truth or falsehood of the legend respecting St Cuthbert's body. ${ }^{70}$ In other words, Catholics had no particular stake in arguing that the body had been incorrupt, it was the controversial purposes to which Raine turned the debate which were problematic. Lingard suggested happily enough that purely non-miraculous causes might have been responsible for delaying the corruption of Cuthbert's body. ${ }^{71}$ At the end of the century, William Brown could still make valid criticisms of Dr Plummer's medical account of the skeleton on the most practical of grounds. But he began his account of the problem with the assumption that Cuthbert's body had to be incorrupt, in a manner which Lingard did not. While Dr Plummer was willing to believe that some natural process of mummification may have been at work on Cuthbert, Brown refused to consider that the body might have been mummified, rather than incorrupt through divine intervention. ${ }^{72}$ Brown returned to the issue again and again during the 1890s and 1900s, displaying great zeal for his patron saint. Ushaw College was clearly dead-set against accepting that Cuthbert's body might be the skeleton which the Anglicans said it was.

Cuthbert's body was not, of course, an issue to incite burning religious hatred. It is striking that so many of the individuals who argued about the state of these relics were on friendly terms in their personal lives. Lingard and Raine met in 1829, shortly after the 
saga of Raine's excavations and book, and the Catholic priest confessed to finding the librarian of Durham Cathedral 'a very industrious and intelligent young man' ${ }^{73}$ Raine's successor William Greenwell was one of the guests at the celebrations to mark twentyfive years of William Brown's residence at St Cuthbert's church in Elvet. ${ }^{74}$ In nineteenthcentury Durham Protestant-Catholic relations were not always warm or sympathetic, but at the level of the scholarly elite they were increasingly polite and respectful as the century progressed. This personal amity between the clergy of different denominations who could still engage in traditional sectarian polemic shows just how secure the Catholic position in English society had become over the course of the nineteenth century.

That century saw many changes, not least, of course, the increasing secularisation and professionalization of scholarship, the importance of which has frequently been exaggerated in the past. Religion remained a real and influential concern underlying the radically different attitudes to Cuthbert's body. Raine's archaeological investigation was aimed at overthrowing the superstitious myths of another age and therefore could be framed as an application of 'the new scholarship' to problems in ecclesiastical history. ${ }^{75}$ But to represent the issue in this way would grossly distort Raine and his contemporaries' understanding of his scholarship, which had as much in common with the confessional polemic of the past as the neutral historiography of the future. Lingard could wield the language of academic integrity against Raine, proving that the dispassionate historian was an influential ideal; nonetheless, his own celebration of good, dispassionate historical work was thoroughly instrumental. Lingard believed that the truth would expose as false those Protestant myths which had become central to English nationalism; 
high-standards in scholarship thus provided a tool which Lingard used to further his confessional ends of justifying the place of Roman Catholics in English life. ${ }^{76}$

The sources do imply that the growing secular ideals of scholarship were having an effect. The mocking 'Monander' in Andrews Penny Orthodox Journal declared Raine $\&$ co. to be no more than a pack of self-confessed grave robbers - the idea that the expansion of knowledge may have justified their actions never even occurred to the writer. ${ }^{77}$ Even Darnell appears to have been uneasy about the impiety of opening Cuthbert's tomb and interfering with the dead. ${ }^{78}$ But at the Society of Antiquaries of Newcastle in 1899, the experienced archaeologist, Dr Greenwell, laughingly dismissed any moral qualms about opening up graves - faced with the imperatives of scholarship such concerns seemed plain silly. ${ }^{79}$ Nonetheless, almost all the texts examined in this paper, those from the end of the nineteenth century as much as those from the beginning, arise from that body of men who inhabited the grey area between the clerical and the academic and who contributed so much to Victorian learning, especially through regional studies.$^{80}$ It is only really at the very end of our period, in the clash between Selby Plummer and William Brown, that we genuinely see the gap between the 'scientific' and the 'superstitious' which features so prominently in traditional interpretations of the nineteenth century. ${ }^{81}$

Acknowledging change does not require us to ignore continuity. The medieval cult of the saints was dead in Victorian Durham, and yet a ghost of it still remained in the passions which some bones could inspire in both devotees and sceptics. For some at least Cuthbert, and his miraculous incorruption, continued to play a key role in local identity and pride. In the nineteenth century, English Catholics continued to put a great deal of faith and fervour into belief in the intercession of the saints and in the continuing 
possibility of miracles. ${ }^{82}$ And when non-Catholics went out of their way to rubbish such beliefs, as Raine did, they were in fact continuing to recognise the power in ideas such as sanctity and relics. Idols have to be smashed only while they still have influence over men. Thus, the excavations and writings which focused on Cuthbert's body throughout the nineteenth century were not signs of a growing scholarly quest for the objective truth. They were not even the battleground between a dawning rationalism and an archaic religiosity. They formed part of a continued engagement by Christians with a concept which, for good or ill, had been part of their religion for centuries. 
*This article is based upon a paper delivered to the University of Oxford Church History Workshop; my thanks to all the members of that group for their kindness and stimulating comments. It was completed and submitted for publication before I became aware of Richard N. Bailey and Eric Cambridge, 'St Cuthbert's Posthumous Biography: A Revised Edition', Peritia, XXVI (2015), 13-27.

${ }^{1}$ Bede, Vita sancti Cuthberti, ed. and trans. Bertram Colgrave in Two Lives of Saint Cuthbert (Cambridge, 1940), ch. xxxvii, pp. 278-81.

${ }^{2}$ Ibid. ch. xlii, pp. 290-5.

${ }^{3}$ Gerald Bonner, 'St Cuthbert at Chester-le-Street', in St Cuthbert, his Cult and his Community to AD 1200, ed. Gerald Bonner, David Rollason and Clare Stancliffe (Woodbridge, 1989), pp. 387-95.

${ }^{4}$ Reginald of Durham, Reginaldi monachi Dunelmensis libellus de admirandis beati Cuthberti virtutibus, ed. James Raine, SS, I (1834), 40-43, pp. 84-90; Capitula de miraculis et translationibus sancti Cuthberti, ed. Thomas Arnold in Symeonis monachi opera omnia, Rolls Series, LXXV (1882), I.7, pp. 257-61.

${ }^{5}$ For the medieval cult of Cuthbert, and the episcopal palatinate of Durham, see Christian D. Liddy, The Bishopric of Durham in the late Middle Ages: Lordship, Community and the Cult of St Cuthbert (Woodbridge, 2008); William M. Aird, St Cuthbert and the Normans: the Church of Durham, 1071-1153 (Woodbridge, 1998); Dominic Marner, St Cuthbert: His Life and Cult in Medieval Durham (2000).

${ }^{6}$ Rites of Durham: being a description or brief declaration of all the ancient monuments, rites, \& customs belonging or being within the monastical church of Durham before the suppression written 1593, ed. J. T. Fowler, SS, CVII (1903), pp. 102-3; Nicholas Harpsfeld, Historia ecclesiastica Anglicana (Douai, 1622), p. 105.

${ }^{7}$ A Raine Miscellany, ed. Angela Marsden, SS, CC (1991), p. 3.

${ }^{8}$ James Raine, Saint Cuthbert: with an account of the state in which his remains were found upon the opening of his tomb in Durham cathedral, in the year MDCCCXXVII (Durham, 1828). 
${ }^{9}$ See esp. C. F. Battiscombe (ed.), The Relics of Saint Cuthbert (Oxford, 1956).

${ }^{10}$ Raine, Saint Cuthbert, p. 228.

${ }^{11}$ Ibid. pp. 66-7.

${ }^{12}$ Richard N. Bailey, 'St Oswald's Heads', in Oswald: Northumbrian King to European

Saint, ed. Clare Stancliffe and Eric Cambridge (Stamford, 1995), pp. 195-209 (p. 200):

'Raine's mind was obsessed with the question of Cuthbert's incorruptibility ...'

${ }^{13}$ Richard N. Bailey, 'St Cuthbert's Relics: Some Neglected Evidence', in Bonner, et al., St

Cuthbert, his Cult and his Community, pp. 231-46 (pp. 233-4); Hugh Norwood and

Nicholas Groves, William Stephen Gilly: An Exceptionally Busy Life (Norwich, 2014), pp.

78-9 n. 15; William Brown, Where is St. Cuthbert Buried? An Old Question Reconsidered

(Durham, 1897), p. 33, relates that it was Darnell who was reported to have jumped into the grave.

${ }^{14}$ Raine, Saint Cuthbert, pp. 215-6.

${ }^{15}$ See Henry Gee, 'City of Durham: General History of the City', in The Victoria History of the County of Durham, ed. W. Page, III (1905), p. 51; Brown, Where is St. Cuthbert

Buried?, p. 6 n; Bailey, in Bonner et al., St Cuthbert, his Cult and his Community, pp. 231-

2; J.M. Tweedy, Popish Elvet: The History of St. Cuthbert's, Durham, 2 vols ([n.p.],1981),

I, 121.

${ }^{16}$ [Anon.], 'Re-Opening of St. Cuthbert's Tomb', Proceedings of the Society of Antiquaries of Newcastle-Upon-Tyne [PSAN], IX.3 (1899), 18-21 (p. 20).

${ }^{17}$ On Van Mildert see Owen Chadwick, The Victorian Church, 2 vols (London, 1966-70), I, 11; Elizabeth A. Varley, The Last of the Prince Bishops: William Van Mildert and the High Church Movement of the early Nineteenth Century (Cambridge, 1992), pp. 123-41. On

Barrington see the next footnote.

${ }^{18}$ Leo Gooch, 'Lingard V. Barrington, et al.: Ecclesiastical Politics in Durham, 1805-29', in Lingard Remembered: Essays to Mark the Sesquicentenary of John Lingard's Death, ed. Peter Philips (2004), pp. 35-64; Shute Barrington, The Grounds on which the Church of England separated from the Church of Rome, stated in a Charge delivered to the Clergy of 
the Diocese of Durham, at the Ordinary Visitation of the Diocese, in the Year 1806, $2^{\text {nd }}$ edn (1807). While William Gilly appears to have taken the approach of non-confrontation during debates concerning emancipation in Durham, he had a reputation for stirring up antiCatholic controversy in the London parish where he served as minister when first admitted to a Prebend at Durham: Norwood and Groves, William Stephen Gilly, pp. 67-8, 83.

${ }^{19}$ One should note, however, that Ushaw College had in 1828 not yet formally accepted Cuthbert as its patron. The first official appearance of Cuthbert in that role seems to have been in 1839: David Milburn, A History of Ushaw College (Durham, 1964), pp. 165-6. ${ }^{20}$ On Lingard's ideals as an historian see Edwin Jones, John Lingard and the Pursuit of Historical Truth (Brighton, 2001).

${ }^{21}$ John Lingard [writing anonymously], Remarks on the "Saint Cuthbert" of the Rev. James Raine, M.A., etc. (Newcastle, 1828), p. 8.

${ }^{22}$ Ibid. p. 61.

${ }^{23}$ Walter Scott, Marmion: A Tale of Flodden Field (Edinburgh, 1808), Canto II.XIV, p. 93: 'There, deep in Durham's Gothic shade, / His reliques are in secret laid; / But none may know the place, / Save of his holiest servants three, / Deep sworn to solemn secrecy, / Who share that wondrous grace.'

${ }^{24}$ John Milner, ‘Account of an Ancient Manuscript of St. John's Gospel, by the Rev. John Milner, F.A.S. in a Letter to the Rev. John Brand, Secretary', Archaeologia, XVI (1812), 17-21 (p. 18).

${ }^{25}$ Raine, Saint Cuthbert, pp. 175 n, 217-20.

${ }^{26}$ See Peter Athanasius Allanson, 'St Cuthbert's Body', Pastoralia, I (1891-2), 110-2, 14851, 220-2, 242-5 (pp. 110-2); this serialised article consists of a transcription from the manuscript of Allanson's History of the English Benedictine Congregation, 1558-1850 (Oxford, 1978), microfiche 72, pp. 525-7. Allanson's work dates from between 1857 and 1876.

${ }^{27}$ Lingard, Remarks, pp. 42, 59-60.

${ }^{28}$ Ibid. p. 69 [unpaginated]. 
${ }^{29}$ Peter Phillips, John Lingard: Priest and Historian (Leominster, 2008), pp. 247-8; Martin Haile and Edwin Bonney, Life and Letters of John Lingard 1771-1851 (1911), pp. 237-9.

${ }^{30}$ John Lingard, The History and Antiquities of the Anglo-Saxon Church, 2 vols (1845), II, 80-81. See also F. C. H., 'St Cuthbert's Remains', Notes \& Queries, $1^{\text {st }}$ ser. XI (1855), 255.

${ }^{31}$ Allanson, Pastoralia, I, 243-5; idem, English Benedictine Congregation, pp. 535-7.

${ }^{32}$ Monander, 'The Biters Bit: a Legend of St. Cuthbert', Andrews' Penny Orthodox Journal of Entertaining Christian Knowledge [hereafter: Christian Knowledge], 15 Jun. 1833, pp. $323-5$.

${ }^{33}$ Charles Eyre, The History of St. Cuthbert: Or, an Account of his Life, Decease and Miracles; of the Wanderings of his Body at Intervals during CXXIV. Years; of the State of his Body from his Decease until A.D. 1542; and of the Various Monuments erected to his Memory, $1^{\text {st }}$ edn (1849), p. 189.

${ }^{34}$ Ibid. p. 194 n. 1.

${ }^{35}$ Ibid. pp. 205-6.

${ }^{36}$ See the review of Eyre's book in the Dublin Review, XXVII (1849), 512-28 (p. 512): 'It is a Catholic priest, and we believe a Catholic priest only, that could properly appreciate the life, the toil, the virtues, and the self-sacrifices, of the monk, priest, anchoret, and bishop, St. Cuthbert'.

${ }^{37}$ The text read, according to both the Durham Chronicle, 24 Sep. 1867, and the Durham Advertiser, 4 Oct. 1867 [both are reprinted in Eyre's $3^{\text {rd }}$ edn of History of St. Cuthbert - see the following note]: 'Infra saxeos gradus tertio et secundo ducentis et ascendentis ad clochim turram jacet thesaurus pretiosus corpus Sancti Cuthberti.' This was clearly a reduced version of the text in the possession of the secular clergy of the Roman Catholic North-Eastern province, with which nonetheless it agreed in substance. Edward Consitt, Life of Saint Cuthbert (1887), pp. 226-7 provides the full text.

${ }^{38}$ Ibid. pp. 228-9; for contemporary newspaper accounts of the investigation: Charles Eyre, The History of St. Cuthbert: Or, an Account of his Life, Decease and Miracles; of the Wanderings of his Body at Intervals during CXXIV. Years; of the State of his Body from his 
Decease until A.D. 1542; and of the Various Monuments erected to his Memory, $3^{\text {rd }}$ edn (1887), pp. 331-44.

${ }^{39}$ Alfred C. Fryer, Cuthberht of Lindisfarne: His Life and Times (1880), p. 203.

${ }^{40}$ F. L. Catcheside, Life of S. Cuthbert, Bishop of Lindisfarne (1879), pp. 55-6.

${ }^{41}$ Eyre, History, $3^{\text {rd }}$ edn, pp. 331-44.

${ }^{42}$ Consitt, Life, pp. 228-38.

${ }^{43}$ Ibid. pp. 238-9, quotation at p. 239. Cf. Eyre, History, p. 206 ( ${ }^{\text {rd }}$ edn, p. 218): 'God, who never worked a miracle to confirm any religious belief but that of the holy Catholic Church, was unwilling that a miracle already worked should subsist when the remains had fallen into the hands of schismatics.'

${ }^{44}$ Consitt, Life, pp. 240-52.

${ }^{45}$ Ibid. pp. 239, 252. Eyre, History, $3^{\text {rd }}$ edn, pp. 325-6, links the contemporary pollution of the industrial North with religious degradation and compares England to a nation under interdict.

${ }^{46}$ J. T. Fowler, St. Cuthbert: A Sermon preached in York Minster on the second Sunday after Christmas, Jan. $2^{\text {nd }}, 1887$ (York, 1887), p. 11.

${ }^{47}$ On which see Chadwick, Victorian Church, II, 109.

${ }^{48}$ William Purcell, Onward Christian Soldier: A Life of Sabine Baring-Gould. Parson, Squire, Novelist, Antiquary 1834-1924 (1957), p. 120.

${ }^{49}$ Sabine Baring-Gould, The Lives of the Saints: March (1872), pp. 358-60 (quotation at p. 359). Despite the statement (p. 337) that the life of Cuthbert 'is extracted from Montalembert's "Monks of the West", Baring-Gould is substantially less non-committal than the count, who contented himself with a comment upon Raine's 'bigoted prejudices' and reference to the fact that Eyre denied the authenticity of the body: Charles, Comte de Montalembert, The Monks of the West from St Benedict to St Bernard, 7 vols (Edinburgh, 1867), IV, p. 429 n.

${ }^{50}$ Baring-Gould could not resist commenting upon Fowler's text for the life of St. Wilfrid (the most troublingly Romanist of Anglo-Saxon saints) that 'I could not assent to the 
favourable view he maintains of the character of the Saint': The Lives of the Saints: October (1877), p. 318.

${ }^{51}$ Brown, Where is St. Cuthbert Buried?, p. 5.

${ }^{52}$ Ibid. p. 6; see also the comments in Consitt, Life, p. 224.

${ }^{53}$ Brown, Where is St Cuthbert Buried?, pp. 22-5.

${ }^{54}$ J. T. Fowler, 'On an Examination of the Grave of St Cuthbert in Durham Cathedral Church, in March, 1899', Archaeologia, LVII (1900), 11-28 (p. 11).

${ }^{55}$ Ibid.; F. J. Haverfield and William Greenwell, A Catalogue of the Sculptured and Inscribed Stones in the Cathedral Library, Durham (Durham, 1899), p. 153; [Anon.], PSAN, IX.3, p. 19.

${ }^{56}$ Fowler, Archaeologia, LVII, pp. 14-15; William Brown, 'St. Cuthbert's Remains', Ushaw Magazine, XXIX (1909), 25-39 (p. 29).

${ }^{57}$ Fowler, Archaeologia, LVII, p. 17; [Anon.], PSAN, IX.3, p. 20; William Brown, 'St. Cuthbert's Grave and Coffin', Ushaw Magazine, IX (1899), 74-88, 117-32, 256-60 (pp. 88, 127).

${ }^{58}$ [Anon.], PSAN, IX.3, p. 20; Haverfield and Greenwell, Catalogue, p. 137; Fowler, Archaeologia, LVII, p. 22.

${ }^{59}$ See [Anon.], PSAN, IX.3, pp. 18-21.

${ }^{60}$ Fowler, Archaeologia, LVII, pp. 17-19.

${ }^{61}$ Selby W. Plummer, St. Cuthbert: Notes on the Examination of his Remains (Newcastle, 1899) [Reprinted from the Northumberland and Durham Medical Journal], pp. 3, 12.

${ }^{62}$ G. W. Kitchin, 'The Contents of St. Cuthbert's Shrine', in The Victoria History of the County of Durham, ed. William Page, I (1905), p. 250.

${ }^{63}$ Ibid. pp. 251-2.

${ }^{64}$ Ibid. pp. 253.

${ }^{65}$ Brown, Ushaw Magazine, XXIX, pp. 25-38, brings the exchange of letters together.

${ }^{66}$ See, for example, the letter from 1791 published by Brown (Ushaw Magazine, XXIX, 38-

9) discussing the suggestion of Thomas Weld, the initial donor of land to Stonyhurst 
College, that Cuthbert's body be moved to Weld's residence at Lulworth Castle, Dorset, so that it might be honorably housed in Catholic hands; in similar vein, Cadwallader Bates feared that Brown's talk about the true burial place of Cuthbert might result in the real relics being discovered by Protestants. At least if the Roman Catholics actively assisted in showing where the body was buried that 'would give us a moral claim to its possession': Letters of Cadwallader John Bates, ed. Matthew Culley (Kendal, 1906), p. 62.

${ }^{67}$ Raine, Saint Cuthbert, pp. 96-7 n; cf. Barrington, Charge, p. 13.

${ }^{68}$ Fowler, Archaeologia, LVII, p. 14; [Anon.], PSAN, IX.3, p. 21 - the words are those of Greenwell.

${ }^{69}$ It ought to be noted that Raine does not appear to have been present when the decisions about re-coffining were being made in 1827 and thus his colleagues may bear more responsibility for the resultant treatment of the relics: Bailey, in Bonner, et al., St Cuthbert, his Cult and his Community, p. 233.

${ }^{70}$ Lingard, Remarks, p. 6 ; he meant here the legend of Cuthbert's incorruption rather than that concerning the secret burial. Also Monander, Christian Knowledge, 15 Jun. 1833, pp. $323,325$.

${ }^{71}$ Lingard, Remarks, pp. 9-12, 65-6.

${ }^{72}$ Plummer, Notes, p. 10, suggests possible causes of mummification, 'eliminating, for the sake of argument, a Divine interference'; Brown, Ushaw Magazine, XXIX, 34. See also Dr Plummer's letter to Dean Kitchin of 1903 (printed in Battiscombe (ed.), Relics, pp. 96-7) wherein he strongly argued for mummification: 'The Monkish legend can easily be explained on scientific grounds' (p. 97).

${ }^{73}$ Haile and Bonney, Life and Letters, p. 239.

${ }^{74}$ Tweedy, Popish Elvet, II, 58.

${ }^{75}$ Ralph Douglas Townsend, 'Hagiography in England in the Nineteenth Century: A Study in Literary, Historiographical and Theological Developments', (unpublished doctoral thesis, University of Oxford, 1981), p. 186: 'The work of James Raine on the history of S.

Cuthbert in the late 1820s showed how effectively the problem of ecclesiastical history 
could be handled by the new scholarship.'

${ }^{76}$ Haile \& Bonney, Life and Letters, pp. 87-8, 166-7, 347; Phillips, John Lingard, pp. 151, 413-14; John Vidmar, English Catholic Historians and the English Reformation, 1585-1954 (Brighton, 2005), pp. 52-74.

${ }^{77}$ Monander, Christian Knowledge, 15 Jun. 1833, pp. 323, 325.

${ }^{78}$ Darnell wrote to Raine on 30 Jul. 1827: 'I wish no evil may befall you for having been engaged in this wicked spoliation of the dead.' Quoted from Bailey, in Bonner, et al., St Cuthbert, his Cult and his Community, pp. 232-3.

${ }^{79}$ [Anon.], PSAN, IX.3, pp. 20-21.

${ }^{80}$ Philippa Levine, The Amateur and the Professional: Antiquarians, Historians and Archaeologists in Victorian England, 1838-1886 (Cambridge, 1986), repeatedly shows the high numbers of Anglican clergy in the historical and antiquarian societies of the Victorian era.

${ }^{81}$ Of course anti-Catholic rhetoric did often set up Protestant rejection of Catholic saints and their miracles as rationalism opposed to superstition: E. R. Norman, Anti-Catholicism in Victorian England (London, 1968), pp. 14-15. But this rejection of post-apostolic miracles was a long-standing part of Protestant theological rhetoric, not an offshoot of rationalism, and could easily exist alongside a conviction in the truth of scriptural miracles: Chadwick, Victorian Church, II, 32.

${ }^{82}$ Mary Heimann, Catholic Devotion in Victorian England (Oxford, 1995), pp. 160-65. 